\section{Helse Førde}

Helse Førde er eitt av fem helseføretak i regionføretaket Helse Vest. Vi har ansvar for spesialisthelsetenesta i Sogn og Fjordane, og vi har over 30 avdelingar med ulike spesialfunksjonar.

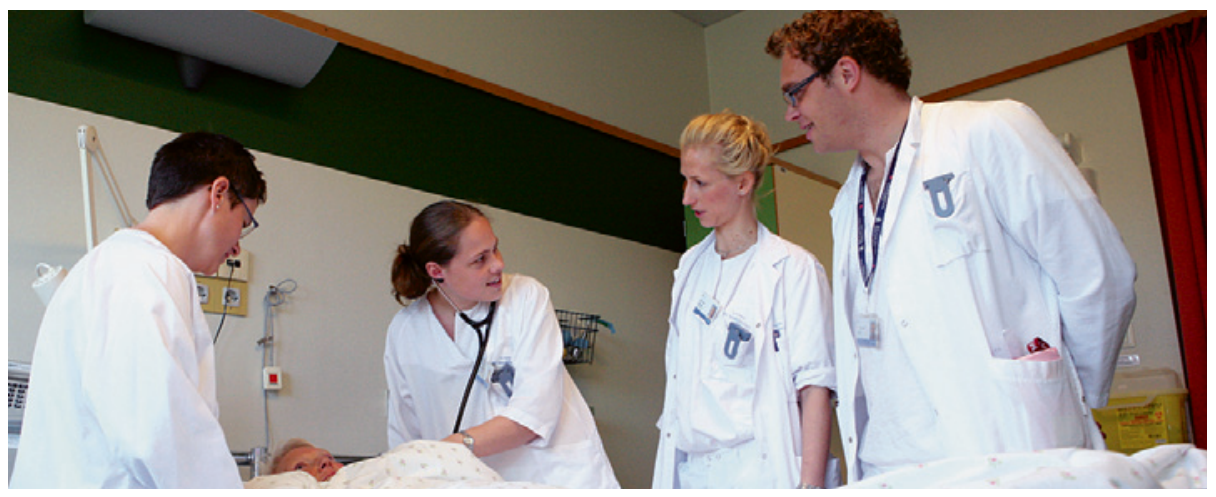

Pasientundersøking. Foto: Helse Førde

Våre fire kjerneområde er pasientbehandling, utdanning av helsepersonell, forsking og informasjon til pasientar og pårørande.

Føretaket har over 2500 tilsette og består av Førde sentralsjukehus, med avdelingar i Florø og Tronvik, Lærdal sjukehus, Nordfjord sjukehus, Nordfjord psykiatrisenter, Indre Sogn psykiatrisenter, Nordfjord BUP og ambulansetenesta.

\section{Førde sentralsjukehus}

Førde sentralsjukehus er eit somatisk og psykiatrisk sjukehus for Sogn og Fjordane fylke. Sentralsjukehuset, som ligg i fylkessenteret Førde, er òg lokalsjukehus for regionane Sunnfjord og Ytre Sogn. I tillegg er det ei avdeling i Florø.

\section{Lærdal sjukehus}

Lærdal sjukehus er lokalsjukehus for Indre Sogn, som omfattar kommunane Lærdal, Årdal, Aurland, Sogndal, Luster, Leikanger og Vik. I tillegg har sjukehuset mange pasientar frå nabofylka Hordaland, Buskerud og Oppland.

\section{Nordfjord sjukehus}

Nordfjord sjukehus har røter tilbake til 1936. Det har i alle år hatt god lokal forankring, i eit lite og oversiktleg miljø. Hovudopptaksområdet for sjukehuset er kommunane Stryn, Hornindal, Eid, Gloppen, Vågsøy, Selje og delar av Bremanger.

\section{Helse Førde - ei moderne verksemd med mange karrieremoglegheiter!}

Utdanning er ei av hovudoppgåvene til spesialisthelsetenesta. I Helse Førde er kompetansen i kontinuerleg oppbygging. Kvart år er det om lag 500 personar i utdanning, spesialisering, praksis eller turnusteneste - studentar, framtidige sjukepleiarar, legar, fysioterapeutar, radiografar, bioingeniørar med meir.

I tillegg til dette har Helse Førde alltid bruk for administrativt tilsette og fagfolk i praktiske yrke som rørleggarar, elektrikarar, snikkarar, portørar, reinhaldspersonale, kokkar og kjøkkenpersonale.

\section{0 yrkesgrupper jobbar for pasienten}

Helse Førde er den største arbeidsplassen i Sogn og Fjordane. Hos oss møter du eit spanande fagmiljø og et føretak med utfordringar og moglegheiter innan ei rekkje område. Det er tilsette på nær 200 ulike fagfelt hos oss - dei kjem frå både inn- og utland - og vi har eit engasjerande og utviklande arbeidsmiljø. Helse Førde er ein arbeidsplass som har ei rekkje gode tilbod til både tilsette og deira familie. Rundt oss har vi ein flott natur som lokkar til ulike fritidsaktivitetar både sommar og vinter, og vi har mange hyggelege lokalsamfunn med alle typar tenester i nærleiken.

Hjelp til å skaffe familietilpassa bustad for våre tilsette er høgt prioritert hos oss, og Helse Førde har tilgang til ei rekkje bustader.
10.11.

FRIST FOR REGISTRERING AV ANNONSER TIL NR. 22/2014 PÅ LEGEJOBBER.NO

\section{Om Legejobber.no}

Legejobber.no er Tidsskriftets stillingsportal for leger og for stillingsannonsører.

Som annonsør kan du nå bestille annonsen døgnet rundt via Legejobber.no. Du registrerer nettannonsen og papirannonsen samtidig.

\section{Som jobbsøker kan du på}

Legejobber.no enkelt søke etter ledige jobber etter spesialitet, geografisk område eller i fritekst.

\section{Ønsker du å motta varsel om ledige stillinger innenfor et bestemt område? På Legejobber.no kan du abonnere på ledige stillinger.}

\section{Priser på stillingsannonser 2014}

* Gjelder for kombinasjon papir/nett.

Format

Størrelse

1/1 side

$185 \times 245$

Pris svart-hvitt

31600

Pris 4 farger

34700

$1 / 2$ s. liggende

$185 \times 112$

Pris svart-hvitt

17000

Pris 4 farger

20000

$1 / 2$ s. stående

$90 \times 245$

Pris svart-hvitt

17000

20000

$1 / 4$ side

$90 \times 112$

Pris svart-hvitt

9000

Pris 4 farger

11000

$1 / 8$ side

$90 \times 45$

Pris svart-hvitt 